\title{
Culpable Participation in Fiduciary Breach
}

\section{By}

\author{
Deborah A. DeMott*
}

Forthcoming in RESEARCH HANDBOOK ON FIDUCIARY LAW (D. Gordon Smith \& Andrew S. Gold, eds.)(Elgar Publishing)

\section{INTRODUCTION}

Most of the time, the connections between fiduciary obligation and tort law receive little theoretical attention. To be sure, scholars engaged with fiduciary obligation occasionally note that the law categorizes breach of fiduciary obligation as a tort, at least in the United States. ${ }^{1}$ In contrast, whether - or to what extent - fiduciary obligation should be understood as a form of bilateral contract has long been a dominant focus for scholarship. In this essay, I make a case for the salience of tort. My specific focus is a type of tortious conduct necessarily linked to breach of fiduciary obligation: participating in a fiduciary's breach of duty, whether by lending substantial assistance or otherwise. The tort subjects the actor who culpably participates in fiduciary breach to liability that's accessory to the liability of the primary tortfeasor, who breached a fiduciary duty. Within a broad understanding of tort law, knowingly to participate in a fiduciary's breach of duty contravenes a right, held by the beneficiary of that duty, not to be mistreated in a particular way. ${ }^{2}$ This accessory tort's elements are well established and relatively stable across

\footnotetext{
*David F. Cavers Professor of Law, Duke University School of Law. Many thanks to Andrew Gold for comments on an earlier draft.

${ }^{1}$ Restatement (SECOND) OF TORTS $§ 874$ (1979), discussed in Deborah A. DeMott, Breach of Fiduciary Duty: On Justifiable Expectations of Loyalty and Their Consequences, 48 ARIZ. L. REV. 925 (2006).

${ }^{2}$ John C.P. Goldberg \& Robert H. Sitkoff, Torts and Estates: Remedying Wrongful Interference
} 
jurisdictions in the United States. ${ }^{3}$ What's controversial is how the tort applies to particular categories of actors, most recently investment bankers who act as target companies' advisors in merger and acquisition ("M\&A") transactions. ${ }^{4}$ In particular, when the Delaware Supreme Court affirmed a $\$ 76$ million judgment against an investment bank that knowingly gave substantial assistance to directors' breaches of fiduciary duty, the size of the award was stunning but the underlying theory of liability was not novel. ${ }^{5}$ The bank's liability was premised on its knowing participation in a wrong committed by the primary defendants, the directors of the bank's corporate client.

Additionally, the essay explores the implications when the primary actor breaches a duty that's not a fiduciary obligation imposed by law but a duty imposed or created by a contract that explicitly eliminates or supplants conventional fiduciary duties. ${ }^{6}$ Accessory actors may knowingly participate in breaches of governance duties in non-corporate entities, such as limited

with Inheritance, 65 STAN. L. REv. 335, 380 ("[e]ach tort defines a right not to be mistreated in a particular way.").

${ }^{3}$ In contrast, English law has been less stable in recent decades. For comparisons with the United States, see Deborah A. DeMott, Accessory Disloyalty: Comparative Perspectives on Substantial Assistance to Fiduciary Breach, in EQUTTY, TRUSTS \& COMMERCE (Paul S. Davies \& James E. Penner eds.)(forthcoming 2017)(hereinafter DeMott, Accessory Disloyalty).

${ }^{4}$ The tort's applicability to lawyers, not my focus here, is a perennial source of controversy. Nor is the law necessarily consistent across jurisdictions. See, e.g, Troice v. Proskauer Rose, L.L.P., 816 F.3d $341\left(5^{\text {th }}\right.$ Cir. 2016)(applying Texas law and dismissing with prejudice case alleging that lawyers and law firms aided and abetted client's Ponzi scheme; under Texas law fraud is not an exception to attorney immunity from suit, including immunity from suits brought by parties other than party-opponents in litigation, when the lawyer's disputed conduct is of the sort in which lawyers engage when representing clients); Neogenix Oncology, Inc. v. Gordon, 133 F. Supp. 3d 539 (E.D.N.Y. 2015)(applying New York law; aiding-and-abetting claim against law firm when client's CFO paid finders' fees to unlicensed brokers survives motion to dismiss and is not entirely duplicative of claim alleging firm breached its fiduciary duty).

${ }^{5}$ RBC Capital Mkts., LLC v. Jervis, 129 A.3d 816 (Del. 2015).

${ }^{6}$ The limited scope of this essay precludes full consideration of issues generated when a contractual provision mimics a fiduciary duty. Section 4 discusses some of the basics. 
partnerships and limited liability companies ("LLCs"). As Delaware law permits, the entity's organizational documents may eliminate fiduciary duties and specify governance obligations solely through contract. In this non-fiduciary turf, another accessory tort may be relevant: wrongful interference with contract. ${ }^{7}$ Although much in this context awaits further development, I identify parallels and overlaps that connect wrongful interference to culpable participation in a breach of fiduciary duty. Both are intentional torts and instances of accessory liability premised on an actor's decision to participate, in some fashion, in another actor's breach of a duty owed to a third party. For both torts, liability requires that the accessory actor's conduct be informed by knowledge of the primary duty or its breach and that it make a causally significant contribution to the wrong suffered by the party to whom the primary actor owes a duty. Both torts also underscore the foundational analytic significance of duty. That is, actors subject to liability on accessory theories do not owe duties that replicate those of the primary wrongdoer to the beneficiary, who are parties linked by a contract or a fiduciary relationship. By committing an intentional tort, accessory actors breach duties they themselves owe.

Situating the inquiry within the ambit of tort law more generally helps explain the distinctive wrongs that these torts represent and helps to explain the structure of this limb of tort law. Thus framed, the outcomes in recent M\&A cases are not departures from well-established tort doctrine. The essay opens with an overview of the elements of these two accessory torts, then turns to theoretical perspectives on accessory liability to identify the distinctiveness of these forms of wrongful conduct. I conclude with illustrative cases demonstrating when these torts have bite in connection with governance obligations, whether defined by conventional fiduciary

${ }^{7}$ For discussion of this point, see section 4 . 
duties or by contract. This account is weighted toward cases from Delaware courts, given Delaware's prominence as a situs for incorporation and for the organization of many noncorporate entities, especially publicly-traded vehicles structured as limited partnerships.

\section{CULPABLE PARTICIPATION IN FIDUCIARY BREACH AND TORTIOUS INTERFERENCE WITH CONTRACT}

\section{Terminology}

Clarity about terminology is crucial for what follows, in part because an accessory actor's participation in a primary breach of duty may take many forms. An accessory's conduct that induces or instigates a breach of fiduciary duty, including through agreement with the fiduciary, occurs prior to- or almost simultaneously with - the fiduciary's decision to breach the duty. In contrast, conduct by an accessory that assists the fiduciary's breach may follow the fiduciary's decision to breach. As we'll see in section 3, some accounts of accessory culpability use the vocabulary of authorship, which is illuminating but can also require adaptation to accommodate the diverse forms of accessory conduct. More significantly, participation in fiduciary breach often is labeled "aiding-and-abetting" liability. ${ }^{8}$ To be sure "aiding and abetting" encompasses assisting a fiduciary breach but not so naturally accessory conduct-like instigation or inducement — that precedes the fiduciary's decision to breach her duty. The essay's chosen generic term, "culpable participation," covers the breadth of accessory conduct, consistently with the cases.

\section{Elements of Culpable Participation}

\footnotetext{
${ }^{8}$ See Richard C. Mason, Civil Liability for Aiding and Abetting, 61 Bus. LAW. 1135 (2006). $-4-$
} 
Like wrongful interference with contract, culpable participation in fiduciary breach is a nominate tort with specified elements that the plaintiff must allege and establish. ${ }^{9}$ Many Delaware cases apply the formulation in Malpiede v. Towson, which requires the plaintiff to show: (1) the existence of a fiduciary relationship; (2) a breach of the fiduciary's duty; (3) the defendant's knowing participation in that breach; and (4) damages to the plaintiff proximately caused by the defendant's breach. ${ }^{10}$ Thus, an accessory's liability is contingent on another actor's breach of duty, but the accessory's liability constitutes an independent wrong, not an instance of vicarious liability. ${ }^{11}$ Although the accessory's liability is joint and several with the fiduciary's, accessory liability does not require that their culpability be identical. As a consequence, as we'll see in section 4 , a defendant may be subject to accessory liability through knowing participation in a fiduciary's negligent breach of duty. Having committed an independent (and intentional) tort, an accessory defendant does not benefit from exculpation available to a negligent corporate fiduciary. ${ }^{12}$ The intentional character of the tort also has implications for insurability and for the accessory's rights to contribution. ${ }^{13}$

As section 1 notes, the requisites for this form of accessory liability do not vary in substance across US jurisdictions, despite some differences in phrasing. ${ }^{14}$ Regardless, when a

\footnotetext{
${ }^{9}$ Over a century ago, Oliver Wendell Holmes proposed that all nominate torts be subsumed in a single formula for liability, a "general theory" of tort liability, premised on acting with the intention of harming another. Oliver W. Holmes, Jr., Privilege, Malice, and Intent, 8 HARV. L. REV. 1 (1894), discussed in Goldberg \& Sitkoff, supra note 2, at 358. Holmes's proposed reduction was controversial. Id. 10780 A.2d 1075, 1096 (Del. 2001).

${ }^{11}$ See DeMott, Accessory Disloyalty, supra note 3. .

${ }^{12}$ English law is to the same effect. PAUL S. DAVIES, ACCESSORY LIABILITY 55 (2016).

${ }^{13} \mathrm{See}$ section 4 on contribution.

${ }^{14}$ See AngioScore, Inc. v. TriReme Med., LLC., 70 F. Supp. 3d 951, 957 (N.D. Cal. 2014)(noting that parties cited California and Delaware law "essentially interchangeably"). 
fiduciary duty is owed to an entity, Delaware law treats culpable participation in breach as wrongdoing that bears on the entity's internal affairs, with the consequence that Delaware law applies. ${ }^{15}$ Additionally, an accessory who culpably participates in a breach of fiduciary duty owed to a Delaware entity may not — via the doctrine of in pari delicto — defend against the claim by charging the entity itself with its fiduciary's wrongful conduct. This is because in pari delicto is inapplicable to a principal's suits against its own fiduciaries, and Delaware positions accessory defendants inside the fiduciary ambit for this purpose. ${ }^{16}$ Reinforcing uniformity across jurisdictions on the basic structure of the tort, Restatement (Second) of Torts section 876 states the general elements requisite for accessory torts in terms comparable to the formulation in Malpiede. ${ }^{17}$

Some accessory defendants are culpable participants in the fiduciary's breach of duty at its point of origin through a concerted plan or an express agreement with the fiduciary. In Heckmann v. Ahmanson, the accessory defendants, a group that had purchased stock in Walt Disney Productions, agreed with the corporation's directors to a greenmail transaction: the

${ }^{15}$ See, e.g., Stewart v. Wilmington Trust SP Servs., Inc., 112 A.3d 271, 319 (Del. Ch.), aff'd, 126 A.3d 1115 (Del. 2015).

${ }^{16}$ See Stewart, 112 A.3d at 319. This outcome was presaged by dictum in In re Am. Int'l Grp. Consol. Derivative Litig., 965 A.2d 763, 822 (Del. Ch. 2009), aff'd sub nom. Teachers' Ret. Sys. of La. v. PricewaterhouseCoopers LLP, 11 A.3d 228 (Del. 2011).

${ }^{17}$ Entitled "Persons Acting in Concert," section 876 states:

For harm resulting to a third person from the tortious conduct of another, one is subject to liability if he

(a) does a tortious act in concert with the other or pursuant to a common design with him, or

(b) knows that the other's conduct constitutes a breach of duty and gives substantial assistance or encouragement to the other so to conduct himself, or

(c) gives substantial assistance to the other in accomplishing a tortious result and his own conduct, separately considered, constitutes a breach of duty to the third person. 
corporation would repurchase the group's stock at a price above market and above the group's acquisition cost, in exchange for the group's agreement not to buy more stock and to dismiss individual claims in ongoing litigation against the directors that sought to block a defensive acquisition transaction. ${ }^{18}$ The court held that if the Disney directors breached their fiduciary duty to the company's stockholders, the greenmail group could be subject to joint liability as an aider and abettor, knowing as its members did that the stock repurchase would be at a price "considerably above market value to enable the Disney directors to retain control of the corporation," and knowing as well that Disney would fund the repurchase by assuming debt in an amount that would adversely affect its credit rating and stock price. ${ }^{19}$ The group would be subject to joint liability with the directors on the basis of a "common plan or design to commit a tort ...."20 Later cases more cleanly differentiate between aider-and-abettor liability and conspirators who adopt the primary actor's tort as their own. ${ }^{21}$

More recent cases illustrate that the linchpin on which an alleged accessory's liability often turns is the element of knowing participation, albeit in the absence of a "common plan or

18168 Cal. App. 3d 119, 214 Cal. Rptr. 177 (1985). .

${ }^{19}$ Id. at 127,214 Cal. Rptr. at 183-84.

${ }^{20} I d$. at 127, 214 Cal. Rptr. at 184. This holding exemplifies liability under Restatement (Second) $\S 876$ (a). Separately, the accessory defendants did not agree to dismiss derivative claims they had asserted against Disney's directors in the same suit. The court held that by filing the derivative claims, the greenmailing group assumed a fiduciary duty to the corporation's other shareholders as to those claims. Id. at 128, $214 \mathrm{Cal}$. Rptr. at 183. This separate holding would support liability under Restatement (Second) $\$ 876$ (c).

${ }^{21}$ See Neilson v. Union Bank of Cal., N.A., 290 F. Supp. 2d 1101, 1134 (C.D. Cal. 2003)(act of aiding and abetting is distinct from primary violation; liability attaches because aider and abettor 'behaves in a manner that enables the primary violator to commit the underlying tort"); Prairie Capital III, L.P. v. Double E Holding Corp., 132 A.3d 35, 63-64 (Del. Ch. 2015)(claim that actor aided and abetted primary actor's fraud is distinct from claim that two actors conspired, acting pursuant to a common plan as stated in Restatement (Second) of Torts $\S 876$ (a); "[i]n some cases the distinction makes a difference. In others, it doesn't.")(footnotes to 
design" or prior agreement. Recent cases also illustrate the range of circumstances that may be congenial to claims of culpable participation, prominent among them post-associational claims. In AngioScore, Inc. v. TriReme Medical, LLC, the founder of a manufacturer of surgical devices subsequently founded a competing firm (which had corporate affiliates) while he was still a director of the manufacturer. The court held that the facts alleged by the plaintiff (the manufacturer) amply supported an inference that the competitors' directors knew that the founder remained on the manufacturer's board. ${ }^{22}$ For one thing, the founder's own knowledge of his breaches of duty to the manufacturer was imputed to the competitors, given his role as an officer and director of those entities. ${ }^{23}$ Although the accessory defendants characterized their conduct as typical or routine, not extraordinary, doing so would not insulate them from liability stemming from sales of a product that competed directly with the plaintiff's.

Most likely courts assess the elements requisite to knowing participation in light of the parties' relationships, in AngioScore the ties between the same individual actor and successivelyformed entities to which he owed fiduciary duties. ${ }^{24}$ In contrast, in In re Answers Corp.

citations omitted).

${ }^{22}$ AngioScore, 70 F. Supp. 3d at 958.

2370 F. Supp. 3d at 958. For a different assessment of knowledge in a post-associational dispute, see Schroeder v. Pinterest, Inc., 133 A.D. 3d 12, 25-26, 17 N.Y.S.3d 678, 689 (2015)(claim by inventor of website application against competitor that allegedly misappropriated application after investor in LLC formed by inventor co-formed new entity-the competitor-and gave it information about application; although inventor stated claim of breach of fiduciary duty against investor under Delaware law given investor's status as a director of LLC at the time he shared information with competitor, aiding-and-abetting claim against competitor fails because inventor did not allege with particularity facts sufficient to demonstrate that competing entity knew of investor's involvement with inventor's LLC, including his fiduciary ties to it).

${ }^{24}$ Although the prospect of financial gain can help establish that an aider and abettor knew of and substantially assisted the primary wrongdoer, financial gain itself is not an element of the tort. See Neilson, 290 F. Supp. 3d at 1127-28 (applying California law, and noting that reference in Heckmann to accessory "“reaping the benefit" of primary breach of duty does not add a 
Shareholders Litigation., in the wake of a merger with a buyout group, shareholders of the target corporation alleged breaches of fiduciary duty by the target's directors, aided and abetted by the buyout group. ${ }^{25}$ The court found insufficient evidence of breach of fiduciary duty by the directors and, more significantly for our immediate purposes, insufficient evidence of knowing participation by the buyout group. In particular, the court was unwilling to interpret negotiations between the two sides as evidence of their exchange of confidential information elsewhere; all that the plaintiffs' evidence established was that "even arm's length negotiators need to email one another to complete a deal and that sometimes they offer suggestions on how to expedite the deal, which the opposing party may accept or reject." ${ }^{26}$ Likewise, in In re Dole Food Co.

Stockholder Litigation, at trial the plaintiffs established breaches of the fiduciary duty of loyalty by Dole's controlling shareholder and the corporation's general counsel in connection with a merger transaction through which the controlling shareholder bought the corporation's remaining shares. ${ }^{27}$ But the plaintiffs' claim against the investment bank that assisted the controlling shareholder failed because the bank itself made no misrepresentations to Dole's shareholders or directors and did not know about or participate in the manipulations and misrepresentations that

substantive requirement to the tort, quoting $168 \mathrm{Cal}$. App. 3d at 127, 214 Cal. Rptr. 177). ${ }^{25} 2014$ WL 463163 (Del. Ch. Feb. 3, 2014).

262014 WL 463163 at * 16.

${ }^{27} 2015$ WL 5052214 (Del. Ch. Aug. 27, 2015). Some cases disapprove of substantial assistance claims against actors who themselves owe fiduciary duties, as Dole's general counsel unquestionably did. Compare Calesa Assocs., L.P. v. American Capital, Ltd., 2016 WL 770251 at *13 (Del. Ch. Feb. 29, 2016)(if characterized as a controlling shareholder, private-equity investor that benefitted through dilutive share issuance would itself owe fiduciary duties and aiding-and-abetting claim would fail for lack of a non-fiduciary defendant; court reserves determination of investor's status so that alternative aiding-and-abetting claim remains available) with Neogenix Oncology, Inc. v. Gordon,133 F. Supp. 3d 539 (E.D.N.Y. 2015)(aiding-andabetting claim against law firm premised on firm's involvement in CFO's payment of finders' fees to unlicensed brokers not entirely duplicative of breach of fiduciary duty claim against 
constituted the fiduciary breaches and gave rise to damages. ${ }^{28}$ To be sure, some bank personnel may have had "reason to be concerned that something may have been amiss" but their client ties, at least at that time, were to the controlling shareholder. And by sharing confidential Dole information with its client, the bank would not categorically breach any duty to the corporation. ${ }^{29}$ Additionally, Dole held that liability premised on culpable participation requires a distinct causal showing, which is that the accessory's conduct was the proximate cause of damage to the plaintiff. ${ }^{30}$ Thus, even had the investment bank in Dole transgressed by dividing its loyalties between the company and its controlling shareholder, the court was unpersuaded that the bank's conduct resulted in harm. Accessory liability also requires that the plaintiff have suffered a loss that's legally cognizable. In Trustees of the Upstate New York Engineers Pension Fund v. Ivy Asset Management, an investment adviser did not disclose to a pension-fund client that it harbored serious doubts about the investment opportunities-in time revealed as a precedent-setting Ponzi scheme—offered by Bernard Madoff. ${ }^{31}$ To be sure the advisor breached its fiduciary client to its client and facilitated Madoff's scheme when the pension fund continued to invest with Madoff with no caution from the advisor, but in the final reckoning the fund did not suffer a legally cognizable loss. Through interim withdrawals ${ }^{32}$ of fictitious "profits" from its

firm).

282015 WL 5052214 at $* 32$.

${ }^{29} 2015$ WL 5052214 at $* 43-44$.

${ }^{30}$ Relatedly, when showing causation will ultimately require showing reasonable reliance, an aiding-and-abetting claim will fail if reliance would not have been justifiable. See Mosier v. Stonefield Josephson, Inc., 815 F.3d 1161, 1167-68 (9 $9^{\text {th }}$ Cir. 2016)(auditor's work could not have furnished substantial assistance to fraud perpetrated by corporation on investors unless potential investors relied on auditor's reports).

${ }^{31} 131$ F. Supp. 3d 103 (S.D.N.Y. 2015).

${ }^{32}$ Totaling $\$ 32,974,742$. Clawbacks cannot recover monies withdrawn more than two years before the date of the bankruptcy petition. Id. at 124 . 
Madoff account that were not subject to clawback as fraudulent transfers, the fund withdrew more than its net investment. ${ }^{33}$ The fund's claim to the balance of fictitious "profits" shown on its final account statement from Madoff did not represent a legally cognizable loss. ${ }^{34}$

Some commentators on accessory liability suggest that a sort of legal hydraulics may be operative. That is, as Richard Mason observes, aiding-and-abetting claims focused on breach of fiduciary duty are relatively easier for plaintiffs than when the primary tort is common-law fraud. ${ }^{35}$ Mason argues that the "elevated duty" owed by the fiduciary may make the nexus between the accessory defendant and harm to the plaintiff more apparent and, the higher the primary duty, the stronger its pull toward accessory liability. Reflecting on English and Australian cases, Joachim Dietrich and Pauline Ridge see the strongest grounds for accessory liability when the accessory's conduct "consists of procurement of the primary wrong," 36 as the greenmail-seeking group may have done in Heckmann. More generally, what's requisite to proving an accessory's knowledge of wrongdoing may be lessened when the accessory derives (or plans to derive) benefit from it. ${ }^{37}$

However, the survey of cases recounted above suggests caution about "legal hydraulics"

\footnotetext{
${ }^{33}$ Totaling $\$ 5,725,258$. In this context, "net" investment is the amount invested minus the amount withdrawn. Id.

${ }^{34} I d$. at 122 .

${ }^{35}$ Mason, supra note 8, at 1163-64. Along these lines, a jurisdiction may recognize aiding-andabetting claims when the primary wrong is breach of fiduciary duty but not fraud. See Grayson v. Anderson, 816 F.3d 262, 272 (4 ${ }^{\text {th }}$ Cir. 2016)(applying South Carolina law in suit brought by Ponzi-fund victims against alleged participants in scheme; although South Carolina cases discuss aiding and abetting breach of fiduciary duty and aiding and abetting an abuse of legal process, no South Carolina case appears to recognize a claim of aiding and abetting common law fraud) For state-by-state data, see Mason, supra note 8.

${ }^{36}$ JOACHIM DIETRICH \& PAULINE RIDGE, ACCESSORIES IN PRIVATE LAW 232 (2016).

${ }^{37}$ Nielson, 290 F. Supp. 2d at 1128 (discussing, in particular, Monsen v. Consolidated Dressed Beef Co., 579 F.2d 793, 799 ( ${ }^{\text {rd }}$ Cir. 1978).
} 
as among the elements requisite to liability. In Dole, the court held the primary defendants - the corporation's controlling shareholder and its general counsel—jointly and severally liable to the corporation's non-controlling shareholders for damages totaling $\$ 148,190,590.18$, finding that both fiduciaries acted intentionally and in bad faith in breaching their fiduciary duties. ${ }^{38}$ But the extreme character in Dole of the primary defendants' breaches did not lessen the causal showing required to impose liability on the accessory defendant, the arguably conflicted investment bank. ${ }^{39}$ Similarly, in Engineers Pension Fund, the investment advisor, having liquidated its proprietary funds' Madoff investments, did not share its suspicions with its client's trustees, while continuing to accept fees linked to the client's Madoff account, which constituted conduct consistent with enabling Madoff's scam to remain operative. Extreme facts, to be sure, but ineffective-indeed beside the point as the court structured its analysis - to negate the consequences of the fact that the pension fund suffered no legally cognizable loss.

\section{Tortious Interference with Contract}

The tort of wrongful interference with contractual relations, like the tort of culpable participation in fiduciary breach, is geared to protect interests defined by other legal doctrines. As defined by Restatement (Second) of Torts section 766, an actor commits the tort through "intentionally and

\footnotetext{
${ }^{38}$ Characterized as a "rarity," the outcome in Dole was framed in a journalistic account as preceded by long-standing frictions between the company's controlling shareholder and hedgefund investors who bought shares "on the eve of the buyout" with the objective of seeking a higher price through post-merger appraisal proceedings. Liz Hoffman, Dole CEO Must Pay Shareholders, WALL ST. J., Aug. 28, 2015, at B4. Reportedly, Dole, which uses the port of Wilmington to import fruit into the United States, "pressed Delaware lawmakers and even the state's governor to tighten laws around shareholder lawsuits ...." Id.

${ }^{39} \mathrm{Of}$ course, a plaintiff's claim against an accessory defendants fails if the primary claim of breach of fiduciary duty fails. See, e.g., In re Molycorp, Inc. S'holder Derivative Litig., $2015 \mathrm{WL}$ 3454925 at* 11 (Del. Ch. May 27, 2015); Higher Educ. Mgmt. Group, Inc. v. Mathews, 2014 WL $5573325 * 13$ (Del. Ch. Nov. 3, 2014).
} 
wrongfully interfering with the performance of a contract ... between another and a third party by inducing or otherwise causing the third person not to perform the contract ...." The elements of the tort, as articulated in Delaware cases, are: (1) a contract, (2) known to the defendant, (3) an intentional act by the defendant that is a significant factor in causing the breach of the contract, (4) without justification, (5) which causes injury. ${ }^{40}$ As comments to Restatement (Second) recognize, interfering with another actor's economic interests may not be wrongful at all and may well be integral to the operation of a free-market economy characterized by robust competition. ${ }^{41}$ And a basic assumption about the primary wrong — breach of contract — is that it does not constitute a tort. Thus, it's crucial how tort law assesses justification for interference. Restatement (Second) structures this inquiry around a list of seven factors. ${ }^{42}$ These are: (a) the nature of the actor's conduct, (b) the actor's motive, (c) the interests of the other with which the actor's conduct interferes, (d) the interests sought to be advanced by the actor, (e) the social interests in protecting the freedom of action of the actor and contractual interests of the other, (f) the proximity or remoteness of the actor's conduct to the interference, and (g) the relations between the parties.

Since the completion of this portion of the Second Restatement in the late 1970's, judicial and academic audiences for legal texts may find multi-factor inquiries that are not ordered by relative importance to be unsatisfying. ${ }^{43}$ In any event, some of the seven Restatement factors

\footnotetext{
${ }^{40}$ Irwin \& Leighton, Inc. v. W.M. Anderson Co., 532 A.2d 983, 992 (Del. Ch. 1987).

${ }^{41}$ RESTATEMENT (SECOND) OF TORTS $\S 767 \mathrm{cmt} . \mathrm{g}$ ("it is thought that the social interest in competition would be unduly prejudiced if one were to be prohibited from in any manner persuading a competitor's prospective customers not to deal with him.").

${ }^{42}$ The seven factors were endorsed as stating Delaware law in WaveDivision Hldgs., LLC v. Highland Capital Mgmt., L.P., 49 A.3d 1168, 1174 (Del 2012).

${ }^{43}$ See Indiana Harbor Belt R.R. Co. v. American Cyanamid Co., 916 F.2d 1174, 1176 ( $7^{\text {th }}$ Cir. $-13-$
} 
relevant to justification overlap with the tort's definitional elements, including the actor's knowledge and intent, plus the nature of the harm. And the analysis in cases applying the factors may imply priorities among them. For example, an actor who interferes with mixed motivesperhaps the protection of its own interests as a creditor as well as a desire to interfere-may succeed in showing justification. ${ }^{44}$ More restrictively, some courts require that interference be through the use of "unlawful means," which under New York law does not encompass persuasion alone albeit knowingly oriented toward interference. ${ }^{45}$

In contrast, culpable participation in a fiduciary's breach of duty is not defined by the means used or sieved through a mesh of justification, nor does the court assess the interests sought to be advanced through participation in the breach. Additionally, broader concerns with freedom of action and social interests are not part of the inquiry into whether an actor culpably participated in a breach of fiduciary duty. But tortious interference with contract, like culpable participation in fiduciary breach, requires that the defendant have acted with knowledge related to legal rights, and the court's inquiry into the means of interference and the defendant's conduct can raise issues related to - if not precisely overlapping with—-those implicated in culpableparticipation claims. In a recent illustration, NAMA Holdings, $L L C v$. Related WMC LLC, the plaintiff established at trial that the defendant entity improperly interfered with its subsidiary's performance of the covenant of good faith implied in contractual instruments under which the

1990)(re-ordering by relative importance to make "more perspicuous" the interrelationships among the six factors set forth in Restatement (Second) $§ 520$ to determine whether an activity is abnormally dangerous).

${ }^{44}$ WaveDivision, 49 A.3d at 1174.

${ }^{45}$ Enzo Life Scis., Inc. v. Adipogen Corp., 82 F. Supp. 3d 568, 604 (D. Del. 2015)(applying New York law; unlawful means requires physical violence, fraud or misrepresentation, civil suits or criminal prosecutions, some forms of economic pressure, or knowing breaches of fiduciary 
subsidiary undertook custodial responsibility to hold monies while competing claimants (including the plaintiff) pursued arbitration against each other. ${ }^{46}$ Characterizing the subsidiary's role as one defined only by contract (and not deciding whether the subsidiary, as a custodian, acted as a common-law agent) ${ }^{47}$ the court held that the subsidiary acted subject to an implied obligation of neutrality. The subsidiary breached this implied obligation by holding the funds until the parent and one of the claimants reached an agreement on a quid pro quo for the release, motivated by the parent's wish to access funds in another account that the same claimant controlled.

Although the parent's conduct toward the NAMA Holdings plaintiff was not independently tortious, the parent's motives and objectives were directed toward harming the plaintiff's contractual interests in the service of the parent's own distinct interests. As will be important for the discussion in section 4, NAMA Holdings makes clear that tortious interference claims are not limited to expressly-delineated contractual terms but extend to the implied covenant of good faith and fair dealing. Although the court held that the parent's means were not themselves tortious (or a breach of fiduciary duty), the parent's self-interested motive was distinct from the business interests of its subsidiary, and the parent realized its ends by agreeing to an explicit quid pro quo from a third party. As section 4 explains, by using problematic tactics - like bribes and other forms of quid pro quos - an actor who interferes with performance under a contract defining governance obligations may invite the assessment that the interference

obligation).

${ }^{46} 2014$ WL 6436647 (Del. Ch. Nov. 17, 2014). I agreed to furnish expert advice as a consultant in this multi-dimensional dispute on issues unrelated to those raised by NAMA Holdings.

${ }^{47} 2014$ WL 6436647 at * 20. The instrument in question expressly disclaimed its creation of any fiduciary relationship. Id. 
was not justifiable and thus was improper.

\section{THE DISTINCTIVE CULPABILITY OF ACCESSORY WRONGDOERS}

The complex and contingent character of the torts explored in this essay means that they may resist capture by generalized accounts of tort law. Consider in this light Arthur Ripstein's recent account, which is centered on the non-instrumentalist ideas that no person is in charge of another (absent a special duty) and that tort law gives effect to the idea that other actors must not interfere with one's own body, property, or reputation, "something you already have," in Ripstein's formulation. ${ }^{48}$ Torts can be categorized into two types of wrongs: using what is another's without that person's authorization, which explains why batteries that cause no harm are actionable; and damaging what is another's, which covers the broad terrain of negligence. ${ }^{49}$ To his credit, Ripstein acknowledges instances that test his typology. For example, fraud requires deceit, which wrongs the subject of the deceit, but it is actionable as a tort only if damage can be shown and, unlike trespass, fraud cannot be committed mistakenly. ${ }^{50}$ Ripstein accommodates fraud into his general typology: "the right at issue is not against being lied to, but rather against being deprived of what you have through deceit." 51 By itself, this rationale understates the complexity of fraud as a tort because the plaintiff must show not only loss but also justifiable

\footnotetext{
${ }^{48}$ ARTHUR RIPSTEIN, PRIVATE WRONGS 7-8 (2016). Ripstein notes that a special relations hip between two persons may engender a duty to aid. $I d$. Special relationships between actors and other persons may create affirmative duties of care toward such persons. See RESTATEMENT (THIRD) OF TORTS: LIABILITY FOR PHYSICAL AND EMOTIONAL HARM $§ 40$ (2012). Additionally, an actor who undertakes to render services to another is subject to a duty of care. See id. $\S 42$. ${ }^{49}$ RIPSTEIN, supra note 48 , at 43-44.

${ }^{50} I d$. at 50 n. 32.

${ }^{51} I d$.
} 
reliance (by the plaintiff) on a misrepresentation made by the defendant. ${ }^{52}$ But, as Ripstein continues, "[g]etting other people to do things by deceiving them is necessarily inconsistent with separate persons pursuing their separate purposes," which captures the gist of reliance..$^{53}$

To some commentators, the separate reliance requirement underscores the relational quality of common-law fraud, distinct from focusing only on the defendant's intentionally wrongful conduct plus economic loss suffered by the plaintiff. ${ }^{54}$ Culpable participation in fiduciary breach, likewise, has characteristics that resist reduction into a simple dichotomy between use- (and interference-) based torts and damage-based torts. Like fraud, culpable participation encompasses both and requires as well that the participation be done knowingly. Culpable participation also requires the occurrence of the primary wrong, however culpable the accessory may be. ${ }^{55}$ Nonetheless, Ripstein's account helps identify the distinctive wrong effected through culpable participation: the justifiable expectation of a fiduciary's loyal service is "something [the plaintiff] already has" and the defendant's knowing participation in the fiduciary's breach causes injury to the plaintiff..$^{56}$

More generally, a fundamental aspect of tort law that culpable participation in a breach of fiduciary duty underscores is the inescapable significance of duty. That is, by culpably

\footnotetext{
${ }^{52}$ ReSTATEMENT (THIRD) OF TORTS: LIABILITY FOR ECONOMIC HARM $\S 11$ (Tent. Draft No. 2, 2014). For an example, see Rosen v. Spanierman, 894 F.2d 28 (2d Cir. 1990)(mother of art collector agreed to and did pay for a painting to be chosen by collector, art dealer having falsely represented authenticity of chosen painting to collector; although collector had good claim against dealer mother did not because mother herself, albeit out of pocket, was not misled by dealer's false statement).

${ }^{53}$ RIPSTEIN, supra note 48, at 50 n. 32.

${ }^{54}$ John C.P. Goldberg et al, The Place of Reliance in Fraud, 48 ARIZ. L. REv. 1001 (2006).

${ }^{55}$ DAVIES, supra note 12, at 32. Put differently, there's no inchoate form of accessory liability.

${ }^{56}$ Ripstein does not address the tort of culpable participation in fiduciary breach and explicitly does not attempt to extend his account to tortious interference with contract. RIPSTEIN, supra note 
participating in a fiduciary's breach of duty, an actor who owed the plaintiff no fiduciary duty becomes jointly and severally liable for harm caused to the plaintiff. An actor's culpable participation, situated as an intentional tort, breaches the actor's duty to those injured by the participation, distinct from the fiduciary's duty to the beneficiary grounded in their relationship. ${ }^{57}$ Moreover, duty is central to understanding why an actor's culpable participation cannot be premised on simple inaction, ${ }^{58}$ even when the actor knows of the fiduciary breach. Unless the actor (here, might we say the in- or non-actor?) owes the plaintiff a duty to take action grounded in a special relationship between them, tort law's baseline rule is no-duty. Like other intentional torts, culpable participation requires a volitional action. As Robert Stevens formulates the general point, we have a right "good against the world" not to be the subject of another's action that constitutes an intentional tort. ${ }^{59}$ An implication of the centrality of duty within tort law, explored in section 4, is that the tort of culpable participation in a breach of fiduciary duty (or, for that matter, in common-law fraud) does not translate into affirmative gatekeeping duties triggered by simple awareness of another actor's breach of duty.

Framed within tort law more generally, the tortfeasors on whom this essay focuses

48, at 179 n. 32.

${ }^{57}$ See Neilson, 290 F. Supp. 2d at 1133 (noting lack of support in California law for proposition that "a party must owe the plaintiff a duty before he or she can be held liable as an aider and abettor"; plaintiff adequately alleged that accounts administrator for investment club assisted primary wrongdoer in Ponzi scheme).

${ }^{58} \mathrm{~A}$ basic premise of negligence liability is that an actor whose conduct has not created a risk of physical or emotional harm to another owes no duty of care to that other, in the absence of an affirmative duty. RESTATEMENT (THIRD) OF TORTS: LIABILITY FOR PHYSICAL AND EMOTIONAL HARM $\S 37$. Likewise, there's no general duty to avoid the unintentional infliction of economic loss on another. RESTATEMENT (THIRD) OF TORTS: LIABILITY FOR ECONOMIC HARM $§ 1$ (a)(Tent. Draft No. 1, 2012). In tort law, "economic loss" means pecuniary damage not arising from injury to the plaintiff's person or from physical harm to the plaintiff's property. $I d$. $\S 2$.

${ }^{59}$ ROBERT STEVENS, TORTS AND RIGHTS 100 (2007). Additionally, such rights "are capable of 
represent inversions of a well-known set of actors, rescuers. Rescuers intervene as strangers to a situation in which another is in peril not as the result of the rescuer's immediate conduct or a risk created by the rescuer. Rescuers intervene-not always successfully_in an attempt to prevent harm or mitigate its adverse consequences for the person in peril. The power of the no-duty baseline can lead to uncomfortable conclusions on normative grounds when an actor could attempt rescue with little effort or cost but chooses not to do so. ${ }^{60}$ On the other hand, once an actor initiates an attempt at rescue, the actor is subject to affirmative duties: to exercise reasonable care while the imperiled person is in the actor's charge; and, if rescue is discontinued. to refrain from leaving the imperiled person worse off than when the rescue was initiated. ${ }^{61}$ What's key to the imposition of duty thus is the rescuer's action to initiate an attempt to rescue. And an actor whose tortious conduct created the peril owes a duty of care to the rescuer, not just the imperiled person. ${ }^{62}$ Like reflected figures seen in a warped mirror, the accessory wrongdoers in this essay intervene in situations in which one party owes another a duty, whether defined and imposed by a fiduciary relationship or by contract. Accessory wrongdoers choose to intervene and act in one fashion or another to cause the underlying breach of duty, doing so knowingly. If successful they leave the person to whom the duty was owed worse off than had they not caused

being infringed without proof of fault. (The right not to be lied to is an obvious exception)." Id. ${ }^{60}$ See RESTATEMENT (THIRD) OF TORTS: LIABILITY FOR PHYSICAL ANDEMOTIONAL HARM $§ 37$ cmt. e (characterizing as "morally repugnant" the proposition that the law condones "an actor's failure to assist another in mortal peril when the actor could do so at little or no cost ...."). Whether a rule requiring attempts to rescue in such circumstances would by some measure be efficient is beside the point, given the foundational no-duty commitment.

${ }^{61}$ RESTATEMENT (THIRD) OF TORTS: LIABILITY FOR PHYSICAL AND EMOTIONAL HARM $\S 44$. If at the time rescue terminates the imperiled person reasonably appears to be in "imminent peril of serious physical injury," the rescuer's duty expands to include a duty of reasonable care concerning the peril itself. $I d$. $\$ 44$ (b).

${ }^{62} I d$. $\S 32$. Liability encompasses any harm suffered by the rescuer so long as it arises from the -19- 
the breach of the primary or underlying duty. Seen this way, liability grounded in an accessory's commission of an intentional tort-a volitional and knowing wrongful action-comes as no surprise.

Finally, how best to reconcile the liability of complicitous actors for wrongs directly perpetrated by other actors is of sustained concern within moral philosophy. In Christopher Kutz's wide-sweeping account, the conception of authorship is crucial: "I am" he writes, "the exclusive author of the actions I perform myself, as well as of the events caused by those actions...By contrast, I am the inclusive author of the actions of the group in which I participate, inclusive because of those actions I am one who could say 'We did it."'63 To be sure, not all accessory tortfeasors are members of groups as ordinarily defined, but they are linked by intentional acts to the primary tortfeasor's wrongful act and its consequences. ${ }^{64}$ Additionally, authorship as a justification for responsibility for the consequences of another's actions does not entail a requirement of originality, i.e., that the idea to commit the wrong originate with the accessory. Copyright law tightly links originality to the legal status of authorship and the rights thereby conferred by the law. ${ }^{65}$ But why one would transpose the copyright definition of authorship into the context of accessory liability in tort law is not obvious. As the cases

attempt to rescue.

${ }^{63}$ CHRISTOPHER KUTZ, COMPLICITY 105-06 (2000)(emphas is omitted).

${ }^{64}$ Focusing on accountability within criminal law, Kutz concludes that inclusive authorship justifies "some form of complicitous liability for aiders, encouragers, and some conspirators," while also concluding that inclusive authorship does not justify current criminal complicity doctrine, including its refusal to differentiate between the culpability of primary and secondary parties. $I d$. at 229. These issues are beyond the scope of this essay, singly focused as it is on private (or civil) law. However, to the extent courts exercise discretion in resolving accessory actors' claims for contribution, an actor's original authorship may undergird a restrictive approach. For a concrete example, see infra text accompanying notes 74-75 and 81-82. ${ }^{65}$ What copyright protects under section 102(a) of the Copyright Act of 1976 are "original works $-20-$ 
recounted in this essay illustrate, the linkages between an accessory's wrongful conduct and that of the primary wrongdoer are varied. Sometimes the accessory is not the originating spark of the primary wrong itself; the accessory's liability instead turns on the accessory's own intentional act informed by the primary wrong, plus the accessory's causal contribution to the primary wrong and loss to its victim.

\section{ACCESSORY WRONGDOERS AND GOVERNANCE DUTIES}

\section{Culpable Participation in Fiduciary Breach}

The analytic and normative frameworks explored so far in this essay apply in settings in which accessory actors culpably participate in breaches of fiduciary duty owed by other actors. Once again, the foundational significance of duty within tort law shapes the role of accessory liability. In particular, absent special circumstances, or a contractual undertaking, an advisor-typically an investment bank - retained by a corporation's board to advise its members does not owe a duty to the corporation's shareholders. ${ }^{66}$ Moreover, typical terms in engagement letters make clear that the advisory bank works only for, and owes duties only to, the corporation, which forecloses an argument that the bank undertook or accepted a duty to shareholders. ${ }^{67}$ But, as section 3 notes, an actor's culpable participation in a fiduciary's breach is consistent with tort law's duty requirement because so to act constitutes an intentional tort; and liability follows for the actor

of authorship."

${ }^{66}$ Joyce v. Morgan Stanley \& Co., 538 F.3d 797, 802 ( $7^{\text {th }}$ Cir. 2008). Accord, In re Shoe-Town, Inc. S'holders Litig., 1990 WL 13475 at* 7 (Del. Ch. Feb. 12, 1990)(dismissing claims that financial advisor owed fiduciary duties to shareholders when adviser that provided fairness opinion was retained by management group taking company private; more generally, no fiduciary duty owed to shareholders arises automatically on part of financial advisor). ${ }^{67}$ Joyce, 538 F.3d at 802. 
when the substantive elements of the tort are established. As it happens, as early as 1990 Delaware authority acknowledged that a financial advisor might be subject to liability to shareholders on an aiding and abetting theory. In In re Shoe-Town Inc. Stockholders Litigation, the financial advisor, retained by a management group taking a company private, was allegedly "closely involved with the management group," as well as with the special committee (alleged to be a sham and to lack independence) and the board, plus was "present and active" in a management group meeting that determined how to proceed to get a deal done. ${ }^{68}$ These factual allegations sufficed for a claim of accessory liability.

Thus, the salience of this tort to recent M\&A litigation represents neither a doctrinal innovation nor an extension of prior law, just the application of well-settled tort doctrine to conduct in connection with a large transaction in which most— but not all —of the target's directors were negligent, not conflicted or otherwise disloyal. ${ }^{69}$ Crucial to the narrative that follows is the fact that - as permitted by corporation statutes in Delaware and other statesnegligent directors do not confront a risk of personal monetary liability, but statutory exculpation does not encompass third-party defendants, like accessory wrongdoers (and is unavailable to directors who breach duties of loyalty or good faith). Preceded within the prior few years by opinions that recognized the availability of aiding-and-abetting claims against financial advisors in the M\&A context and expressed concerns about investment banks with conflicted interests, ${ }^{70}$

\footnotetext{
${ }^{68}$ In re Shoe-Town, $1990 \mathrm{WL} 13475$ at * 7-8.

${ }^{69}$ For assertions to the contrary, see The Delaware Courts and the Investment Banks, Oct. 30, 2015, www.wlrk.com/webdocs/wlrknew/AttorneyPubs/WLRK.24965.15.pdf (posted by Martin Lipton)(noting "doctrinal innovation that first appeared about a year ago" and questioning whether aiding and abetting liability, "which is historically akin to civil conspiracy," can "fairly be extended to regulate banker conduct?").

${ }^{70}$ See In re Toys "R" Us, Inc. S'holder Litig., 877 A.2d 975 (Del. Ch. 2005)(questioning general 
In re Rural Metro Corp. Shareholders Litigation commanded much attention. Unusually, the case proceeded through trial, which generated a factually rich account of interactions between two M\&A advisors, the board, and the special committee appointed by the target's board. ${ }^{71}$ In general, the lead bank structured the sale process with the objective-not initially disclosed to Rura/Metro's directors — of facilitating a financing role for itself in a sale of Rural Metro's direct competitor. The structure involved an unusual two-track bidding structure that generated few expressions of interest in buying Rura/Metro. The lead bank also manipulated the directors' deliberations by altering its valuation analysis so that the bid favored by the bank-prompted by its quest to obtain a role in financing that bid-looked better. And the proxy statement sent to Rura/Metro's shareholders failed fully to disclose these conflicting interests and other shenanigans. ${ }^{72}$

Separately, the trial court had occasion to analyze the lead bank's culpability relative to that of a secondary advisor and members of the special committee, two of whom had personal interests in the transaction that made them ineligible for exculpation, which is unavailable to directors who breach duties of loyalty or good faith. Alone among the defendants, the lead bank did not settle prior to trial and later sought contribution via a settlement credit against the court's judgment of $\$ 91$ million ${ }^{73}$ which represented the difference between the target's value as a

propriety of "staple" financing via acquisition financing offered by target's M\&A advisor to prospective bidders); In re Del Monte Foods Co. S'holder Litig., 25 A.3d 813 (Del. Ch. 2011)(M\&A advisor to target, inter alia, covertly assisted potential bidders in structuring joint bid). See also In re El Paso Corp. S'holder Litig., 41 A.3d 432 (Del. Ch. 2012)(M\&A advisor owned 19\% equity interest in prospective buyer; advisor's team led by banker with large personal shareholding in buyer).

7188 A.3d 54 (Del. Ch. 2014)(Rural I).

${ }^{72}$ RBC Capital Mkts., LLC v. Jervis, 129 A.3d 816, 860-61 (Del 2015).

${ }^{73}$ The full amount was $\$ 91,323,554,61$. 
going concern and the amount its shareholders received through the merger. Resolving questions of first impression under Delaware's statutory regime governing contribution among joint tortfeasors, the court reduced the amount of the lead bank's liability to $\$ 76$ million. ${ }^{74}$ Crucial to this result was the court's holding that the Delaware statute does not bar all intentional tortfeasors from seeking contribution. ${ }^{75}$ The Delaware Supreme Court affirmed on both liability and the judgment amount in RBC Capital Markets, LLC v. Jervis ${ }^{76}$ although, as we'll see, it formulated the duty of M\&A advisors more narrowly than did the Court of Chancery.

What's most memorable about $R B C$ Capital is neither its application of what this essay argues is well-settled doctrine nor the jumbo-sized judgment amount, but the character of the lead bank's conduct toward its immediate advisees, the directors of the target corporation, who breached their fiduciary duties to shareholders by selling the company via a merger transaction daunted by a poorly structured process and inadequate disclosure to shareholders. In the overall assessment of both courts, the bank engaged in "fraud on the board." 77 At least since the late 1980 's, Delaware authority has recognized that an advisor's failure to disclose material facts concerning its own wrongdoing, including its conflicted interests, constitutes fraud on the

\footnotetext{
${ }^{74}$ In re Rural/Metro Corp. S'holders Litig., 102 A.3d 205 (Del. Ch. 2014)(Rural II). The full amount was $\$ 75,798,550.33$.

${ }^{75}$ Rural II, 102 A.3d at 237. The statute-the Delaware Uniform Contribution Among Tortfeasors Law ("DUCATA") — contains no language barring intentional tortfeasors from contribution. See Del. Code Ann., tit. 10, $\$ 6302$ (a)(stating that "[t]he right of contribution exists among joint tortfeasors"), Although Rural II did not imply a categorical bar to intentional tortfeasors, it held that a court retains discretion to deny contribution. Rural II, 102 A.3d at 237. Permitting any contribution to intentional tortfeasors places Delaware in the minority among states, id., but in accord with Restatement (Third) of Torts. See RESTATEMENT (THIRD) OF TORTS: APPORTIONMENT OF LIABILITY $\S 23$, cmt. 1 (2000)(liability for intentional tort does not preclude contribution).

76129 A.3d 816 (Del. 2015).

${ }^{77}$ See $R B C$ Capital, 129 A.3d at 865; Rural II, 102 A.3d at 205. 
advisee (in the M\&A context, the target company's directors). ${ }^{78}$ The underlying principle is a long-standing component of the common law of fraud, which premises liability on an actor's failure to speak when the actor is under a duty to do so, as well as on affirmatively made misrepresentations. ${ }^{79}$ The principle's applicability in this context is another illustration of the linkage between accessory liability and other components of tort doctrine, here because Rura/Metro's shareholders themselves were not directly owed a duty by the board's advisor and because the initial audience for the advisor's misrepresentation-through-silence was the board, not the shareholders. ${ }^{80}$

As a consequence of the bank's fraud on the board, the trial court applied the equitable doctrine of unclean hands to bar the bank from contribution via settlement credit for the portion of damages stemming from the board's reliance on false and incomplete information furnished by the bank when the board-failing attentively to monitor an advisor it then knew to be seriously conflicted - approved the merger. ${ }^{81}$ Finally, framing the bank's conduct within the broader terms explored in Section 3, its active manipulation of the board's deliberative and decision-making processes stemmed from a deliberate campaign actively to dupe the board. ${ }^{82}$ Its conduct seems to constitute original authorship of the board's breaches of duty, beyond withholding material information or joining in as an inclusive author of another actor's breach, in

\footnotetext{
${ }^{78}$ Mills Acq. Co. v. MacMillan, Inc., 559 A.2d 1261, 1283 (Del. 1988).

${ }^{79}$ RESTATEMENT (THIRD) OF TORTS: LIABILITY FOR ECONOMIC HARM $§ 13(\mathrm{~b})($ Tent. Draft No. 2, 2014)(actor "in a fiduciary or other relationship with another that obliges the actor to make disclosure" subject to liability when that actor fails to disclose material information).

${ }^{80}$ As Section 3 notes, the reliance requisite to common-law fraud limits potential plaintiffs. ${ }^{81}$ Rural II, 102 A.3d at 239.

${ }^{82}$ See Singh v. Attenborough, 137 A.3d 151, at *2 n.7 (Del. 2016)(mem.)(characterizing bank's conduct in RBC Capital: "for [its] own motives, it 'intentionally duped' the directors into breaching their duty of care")(quoting RBC Capital, 129 A.3d at 865). 
Christopher Kutz's terminology.

RBC Capital situates the analysis of duty in this context within the now-familiar terrain of the particular intentional tort consisting of culpable participation in another actor's breach of fiduciary duty. In dictum, the Court of Chancery cast duty in broader and uncharted terms by situating financial advisors in M\&A transactions as "gatekeepers" because they provide consequential expert services to non-expert clients. ${ }^{83}$ Although the dictum did not sketch out all implications, one likely candidate would be that undertaking to serve as an M\&A advisor creates a relationship on the basis of which the law imposes affirmative duties. But the dictum did not elaborate the implications, including to whom such duties are owed and what conduct would satisfy them. RBC Capital rejects the dictum, instead emphasizing that "[t]he banker is under an obligation not to act in a manner that is contrary to the interests of the board of directors, thereby undermining the very advice that it knows the directors will rely upon in their decision making processes." ${ }^{84}$ The duty analysis in $R B C$ Capital also emphasizes the role of contract in shaping an advisor's engagement. ${ }^{85}$ Thus, if a bank agrees to provide only limited services to target directors in connection with a transaction, the bank is not subject to liability as an accessory to the directors' breach of duty on the theory that, had the bank undertaken to do more, its expanded service would have prevented loss suffered by shareholders. ${ }^{86}$ RBC Capital does not reject the possibility that an engagement agreement, in addition to defining the scope of the engagement, might also define and delimit an advisor's responsibilities to its client; but the

\footnotetext{
${ }^{83}$ Rural Metro I, 88 A.3d at 88.

${ }^{84}$ RBC Capital, 129 A.3d at 865 n. 191.

${ }^{85} \mathrm{Id}$.

${ }^{86}$ Houseman v. Sagerman, 2014 WL 1600724 at * 10 (Del. Ch. Apr. 16, 2014)(no duty for bank to "provide all or none of the financial services [bank] offers in valuing and marketing a 
bank's actual engagement letter used only general language to disclose the bank's conflicts and "disclosed none of the conflicts that ultimately emerged." ${ }^{87}$ Later cases, not explored here, make clear the significance of full disclosure to shareholders in connection with an uncoerced vote to approve a merger: this insulates the transaction from judicial inquiry into its merits and forecloses aiding-and-abetting claims against accessory actors by dooming claims that the target's directors breached their fiduciary duties. ${ }^{88}$

It's open to question whether the regime of accessory liability recounted above is optimal to deter conflicts on the part of M\&A advisors and, more broadly, to serve investors' interests, given the low likelihood that directors of target companies would confront a significant risk of personal monetary liability. Andrew Tuch observes that by relying on a form of secondary liability, the accessory liability regime opens up the possibility that "a brazenly disloyal M\&A advisor may cause real harm without either misleading the board or creating an informational vacuum," thereby arguably positioning itself beyond the risk of accessory liability, ${ }^{89}$ as would surely be true as well when directors, notwithstanding their advisor's disloyalty, do not breach their duties..$^{90}$ Acknowledging that Delaware's options are limited, Tuch urges Delaware courts to provide fuller guidance to directors on structuring and overseeing relationships with M\&A advisors, and, venturing further, to consider restructuring the confines of duty to reposition M\&A

company").

${ }^{87} 129$ A.3d at 865 n. 191.

${ }^{88}$ See In re Volcano Corp. S'holder Litig., _ A.3d _, 2016 WL 3626521 at * 18 (Del. Ch. June 30, 2016), relying on In re KKR Fin. Holdings LLC S'holder Litig. v. Corwin, 101 A.3d 980, 1003 (Del. Ch. 2014), aff'd sub nom. Corwin v. KKR Fin. Holdings LLC, 125 A.3d 304 (Del. 2015).

${ }^{89}$ Andrew F. Tuch, Banker Loyalty in Mergers and Acquisitions, 94 TEXAS L. REV. 1079, 1146 (2016).

${ }^{90} I d$. For example, the conclusion that there's no breach of duties by directors seems to follow 
advisors in direct relationships to shareholders. ${ }^{91}$

\section{Altemative Entities and Contractual Governance Duties}

Setting aside any qualms about the optimality of the accessory liability regime premised on breach of fiduciary duty, we turn now to a setting predominantly characterized by uncertainty about applicable legal doctrine. As Section 1 noted, entities that are not corporations may, as permitted by state organizational law, be structured so that governance duties are specified entirely by contractual provisions that eliminate or supplant conventional fiduciary duties. Enough time has elapsed since Delaware's enactment of alternate-entity statutes permitting the elimination of fiduciary duties to generate thoughtful assessments of the consequences. Reflecting on their experience adjudicating many alternate-entity disputes, Leo Strine and J. Travis Laster concluded that what the statutes enabled was not bargained-for contract terms, but the imposition of terms on a take-it or leave-it basis by alternate-entity promoters and managers. ${ }^{92}$ And liberated to impose their own terms, managers were often caught by infelicitous drafting, while generalized or standardized formulations of governance duties failed to emerge. ${ }^{93}$ Focusing on an important subset of alternate entities, master limited partnerships that are publicly-traded, Sandra Miller and Karie Davis-Nozemack concluded that the one-sided cast of governance terms significantly disadvantaged investors, most of them individuals over the age of fifty who seek secure income-generating investments, thereby calling into question whether investment into such entities is sufficiently informed and adequately discounts for the risks posed

from a fully informed and uncoerced shareholder vote to approve the transaction.

${ }^{91} I d$. at 1149.

${ }^{92}$ E. Leo Strine \& J. Travis Laster, The Siren Song of Unlimited Contractual Freedom, in RESEARCH HANDBOOK ON PARTNERSHIPS, LLCS AND ALTERNATE FORMS OF BUSINESS ORGANIZATIONS 12-13 (Robert W. Hillman \& Mark J. Loewenstein, eds. 2015). 
by the absence of fiduciary duties. ${ }^{94}$ For Miller and Davis-Nozemack, in publicly-traded entities, "fiduciary duty waivers...should end."95

Perhaps unsurprisingly, M\&A transactions in the alternate entity world raise issues about accessory culpability comparable to those explored in Section 3, but the application of general doctrine in this context is undeveloped. An important starting point is that, although Delaware statutes permit the alteration or elimination of fiduciary duties within LLCs and partnerships, these statutes do not permit the elimination of the implied covenant of good faith and fair dealing. The implied covenant differs from fiduciary-duty concepts of good faith because its temporal focus is ex ante, not the time of the alleged breach, and substantively the implied covenant envisions, not loyalty to the counterparty, but "faithfulness to the scope, purpose, and terms of the parties' contract." ${ }^{96}$ By attempting to take advantage of a procedure specified in a contractual variant of fiduciary duty — such as obtaining a fairness opinion from a qualified financial advisor to bless a conflicted M\&A transaction — a general partner may breach the implied covenant when its conduct is arbitrary or unreasonable. ${ }^{97}$ For example, hypothesized the Delaware Supreme Court, "suppose the controller [general partner] outright bribes the financial

${ }^{93}$ Id. at 27.

${ }^{94}$ Sandra K. Miller \& Karie Davis-Nozemack, Toward Consistent Fiduciary Duties for Publicly Traded Entities, 68 FLA. L. REV. 317-18 (2016).

${ }^{95}$ Id. at 320 .

${ }^{96}$ ASB Allegiance Real Estate Fund v. Scion Breckenridge Managing Member, LLC, 50 A.3d 434, 442 (Del. Ch. 2012), aff'd in part and rev'd in part on other grounds, 68 A.3d 665 (Del. 2013). For a theoretical account of this distinction, see Daniel Markovits, Sharing Ex Ante and Sharing Ex Post: The Non-Contractual Basis of Fiduciary Relationships, in PHILOSOPHICAL FOUNDATIONS OF FIDUCIARY LAW (Andrew S. Gold \& Paul M. Miller eds. 2014). ${ }^{97}$ Gerber v. Enterprise Holdings, LLC, 67 A3d 400, 420 (Del.), overruled on other grounds by Winshall v. Viacom Int'l, Inc., 76 A.3d 808 (Del. 2013). 
advisor to opine (falsely) that the transaction is fair."98 Paying the bribe would, in the court's assessment, breach the implied covenant. ${ }^{99}$

But would a financial advisor, induced by a bribe to falsify its opinion, itself be subject to liability if the falsified opinion contributed to another actor's breach of its contractually-specified governance duties? And what of financial advisors whose problematic conduct is less extreme than taking a bribe or some other explicit quid pro quo? For example, in In re El Paso Pipeline Partners, L.P. Derivative Litigation, a financial advisor opined on the fairness of transactions through which a corporate parent sold two subsidiaries to a limited partnership it controlled through an LLC that served as the limited partnership's sole general partner. ${ }^{100}$ The advisor used a standard engagement letter that charged a fee of $\$ 500,000$ plus expenses, the entire fee being contingent on the advisor's issuance of a fairness opinion. In the latter of two transactions, the court held that the general partner breached the limited partnership agreement because the committee designated by the agreement to assess conflict transactions did not form the subjective belief, as the agreement required, that purchasing the subsidiary was in the limited partnership's best interest. To be sure, the general partner did not bribe the financial advisor to issue a fairness opinion - notwithstanding the all-or-nothing quality of the contingency-fee arrangement—but in the court's assessment the advisor failed to perform the work of an advisor to the committee, instead seeking only to "make the price that Parent proposed look fair," the advisor's "real client" being the deal on which its entire fee depended. ${ }^{101}$ Although the advisor's conduct appears potentially consistent with the factual requisites for some form of accessory liability, the

\footnotetext{
${ }^{98}$ Gerber, 67 A.3d 400, 420.
}

${ }^{99} \mathrm{Id}$.

${ }^{100} 2015$ WL 1815846 (Del. Ch. Apr. 20, 2015). 
court deemed the secondary liability claims waived after the plaintiffs did not develop them in a meaningful fashion. ${ }^{102}$

Helping to explain why these theories may be underdeveloped, Miller and DavisNozemack note discrepant approaches as between the Delaware Supreme Court and the Court of Chancery. ${ }^{103}$ In Gerber, not only did the Supreme Court hypothesize conduct by a general partner that would breach the implied covenant by paying a bribe, it remanded the case to the Court of Chancery to assess the legal sufficiency of claims that the accessory defendants tortiously interfered with contract rights and aided and abetted the general partner's breach of duty. ${ }^{104}$ But opinions from the Court of Chancery dismiss the possibility of claims for aiding and abetting a breach of contract, which may also have stymied the development of tortious interference claims in this context. ${ }^{105}$ It's hard to see a principled basis for a categorical exclusion of accessory liability in the alternate-entity world. After all, unjustified interference with another party's contractual rights is a well-established tort, as cases like NAMA Holdings illustrate for Delaware. To be sure, the interfering actor in that case was a parent corporation, not a third-party advisor, but that difference seems immaterial to the reach of the general principle. ${ }^{106}$

${ }^{101}$ In re El Paso, 2015 WL 1815846 at * 24.

${ }^{102} I d$. at $* 2$.

${ }^{103}$ Miller \& Davis-Nozemack, supra note 94 , at 303-04.

${ }^{104}$ A year later, Gerber settled. See 2014 WL 2967718 (Del. Ch. July 1, 2014)(trial order). ${ }^{105}$ See Miller \& Davis-Nozemack, supra note 94, at 303 (discussing Zimmerman v. Crothall, 2012 WL 707238 at*19 (Del. Ch. 2012) and Allen v. El Paso Pipeline GP Co., 113 A.3d 167, 194 (Del. Ch. 2014).

${ }^{106}$ Recently the Court of Chancery acknowledged in dictum that the implied covenant could be breached when the organizational agreement calls for approval by a committee of independent directors if the general partner bribed the committee. The bribe-induced approval of a conflict transaction would "fundamentally deprive the unitholders [in the limited partnership] of the benefit of the bargain, the protection of an independent committee." See Employees Ret. Sys. v. TC Pipelines GP, Inc., 2016 WL 2859790 (Del. Ch. May 11, 2016). 


\section{CONCLUSION}

The central claim in this essay is that connections between tort law and fiduciary obligation

should not be overlooked. ${ }^{107}$ Explaining the distinctive wrongfulness of assisting in a fiduciary's breach of duty requires situating the inquiry within the framework of tort doctrine more generally. Actors who culpably participate in a fiduciary's breach themselves, as intentional tortfeasors, breach a duty to the fiduciary's beneficiary; they contravene the beneficiary's right not to be mistreated in this particular fashion. obligation.

${ }^{107}$ But I do not propose that tort law does or should subsume the entirety of fiduciary 